\title{
Influence of Anguillicola crassus (Nematoda) and Ichthyophthirius multifiliis (Ciliophora) on swimming activity of European eel Anguilla anguilla
}

\author{
M. Münderle*, B. Sures, H. Taraschewski \\ Zoologisches Institut, Ökologie/Parasitologie, Universität Karlsruhe, Kornblumenstraße 13, 76131 Karlsruhe, Germany
}

\begin{abstract}
We investigated the swimming activity of 70 European eels Anguilla anguilla in relation to natural infection with 2 parasite species: the eel-specific swimbladder nematode Anguillicola crassus and the non-specific skin and gill protozoan Ichthyophthirius multifiliis. We measured how long individual eels exposed to a water current in a swimming channel with a steady-stream profile could withstand the water current. The parasites affected the swimming behaviour of eels in different ways. The maximum period of time the fish were able to swim against the current was not correlated with infection by A. crassus. In contrast, infection with I. multifiliis reduced the swimming time. The protozoan has a higher pathogenicity than the swimbladder nematode, at least in closed systems, where I. multifiliis is able to spread within a few days. Reduction in swimming capacity after infection with the ciliate averaged $47 \%$ compared to capacity prior to infection. Thus, our results do not support the previously suggested strong negative relation between swimming activity of eels and intensity of $A$. crassus infection, at least in the short-term. However, there are indications in the literature that the pathological effects of $A$. crassus on the eel swimmbladder may involve a higher energy demand, possibly manifested in a prolonged spawning migration. As a result, eels heavily infected with this parasite may arrive too late at the spawning site to participate in mating. This could ensure a selection of 'good genes'.
\end{abstract}

KEY WORDS: Swimming activity - European eel · Anguilla anguilla $\cdot$ Anguillicola crassus · Ichthyophthirius multifiliis · Pathology · Pathogenicity · Behaviour · Sexual mate choice

\section{INTRODUCTION}

The swimbladder nematode Anguillicola crassus (Dracunculoidea: Anguillicolidae) is an eel-specific parasite, introduced into Europe from Eastern Asia, where the Japanese eel Anguilla japonica serves as the natural definitive host (Moravec \& Taraschewski 1988, Køie 1991, Kennedy 1993a,b). The first occurrence of $A$. crassus in Germany was recorded in 1982 (Neumann 1985). Since then, the parasite has successfully spread through Europe and attained high prevalences and intensities within populations of the indigenous European eel Anguilla anguilla (Taraschewski et al. 1987, Moravec \& Taraschewski 1988, Moravec 1992, Würtz et al. 1998, Sures et al. 1999a). The parasite has also colonized populations of the European eel in North Africa (Maamouri et al. 1999) and spread to
North America, where Anguilla rostrata was adopted as the final host (Johnson et al. 1995). In addition to the numerous reports on the biology and development of A. crassus in European eels and in the intermediate and paratenic hosts of the parasite (Egusa 1979, De Charleroi et al. 1990, Kennedy \& Fitch 1990, Bonneau et al. 1991, Thomas 1993, Knopf et al. 1998), there has also been an interest in the adverse effects of this parasite on its host (e.g. Moravec \& Konecny 1994, Székely 1994, Sures et al. 1999b). Histopathological studies have been conducted which have demonstrated thickening of the swimbladder wall, inflammation, infiltration of white blood cells, fibrosis, changes in the epithelial cells in infected swimbladders and altered gas compositions of this hydrostatic organ (Hartmann 1989, Van Banning \& Haenen 1990, Molnár 1993, 1994, Molnár et al. 1995, Würtz et al. 1996, Würtz 
\& Taraschewski 2000). Furthermore, the physiological and immunological responses of eels against $A$. crassus have been investigated (Nielsen \& Buchmann 1997, Kelly et al. 2000, Knopf et al. 2000a,b, Sures et al. 2001, Sures \& Knopf 2003). According to these studies it seemed likely that eels with severe swimbladder alterations are incapable of migrating to their spawning grounds (Würtz et al. 1996). Sprengel \& Lüchtenberg (1991) reported that eels infected by A. crassus were handicapped in swimming compared to uninfected controls, and speculated whether these eels would be able to reach the Sargasso Sea.

We performed swimming experiments using eels naturally infected with Anguillicola crassus to check whether their swimming ability is affected by the nematode. The swimming ability of eels was also investigated using fish parasitised by the protozoan Ichthyophthirius multifiliis. The rapid life cycle and the enormous reproduction of the trophozoite stages of this pathogenic generalistic parasite result in massive infection pressure in closed systems such as aquaria. Under these conditions I. multifiliis may lead to mass mortality if not treated (Limanskii et al. 1984, Ewing \& Kocan 1987, Ewing et al. 1988, Schmahl et al. 1992, Scholz 1999).

The aim of the present study was to determine the maximum swimming period of eels infected with Anguillicola crassus, from which we could determine whether infection by this neozoic parasite is likely to prevent the eels from reaching their spawning grounds in the Sargasso Sea. Uninfected eels and eels infected with a highly pathogenic ectoparasite (I. multifiliis) served as controls.

\section{MATERIALS AND METHODS}

Experimental design. We collected 70 eels $(40.3 \pm$ $2.7 \mathrm{~cm}, 81 \pm 16 \mathrm{~g}$ ) from the River Weser by electrofishing in May 2000. Eels were kept individually in 30 to $60 \mathrm{l}$ compartments, equipped with a polypropylene tube to provide a refuge. For the swimming experiments, individual eels were placed in a swimming channel (Fig. 1). A tube was installed within the channel that guaranteed a constant-stream profile as well as a constant current of $0.62 \mathrm{~m} \mathrm{~s}^{-1}$, as monitored by a flow meter. The swimming activity of each eel was measured against the current with a stopwatch. Every eel was made to swim 3 times in the channel with a $2 \mathrm{~d}$ recovery phase between each trial. The maximum period of swimming was recorded for each eel. Swimming was considered to end when an eel passively drifted with the current into a net at the end of the tube. If eels swam longer than 10 min against the current, the experiment was stopped.

Additionally, the swimming activity of eels prior to and following infection with Ichthyophthirius multifiliis was recorded. Eels that had already been used for the swimming experiments were randomly selected and maintained together with eels naturally infected with I. multifiliis; 4 d post-infection, the eels infected in this manner were then re-introduced into the swimming channel.

At the end of the experiments all eels were killed, measured, weighed and immediately examined for parasites according to standard protocols (e.g. Sures \& Streit 2001). All adult Anguillicola crassus were counted and dried at $50^{\circ} \mathrm{C}$ to determine dry weight.

In order to quantify infection with Ichthyophthirius multifiliis, the number of trophozoites $\mathrm{cm}^{-2}$ eel skin were counted under a binocular microscope immediately after swimming ended. We also examined the eels' gills for I. multifiliis, but since they were less densely infected than the skin, we did not count the number of trophozoites.

Statistical analysis. According to the abundance and dry weight of the Anguillicola crassus they bore, eels were divided into 4 classes (I: uninfected; II: 1 to 5 nematodes, 0.1 to $1.0 \mathrm{mg}$ dry wt; III: 6 to 10 nematodes, 1.1 to $25.0 \mathrm{mg}$ dry wt; IV: $>10$ nematodes, $\geq 25.1 \mathrm{mg}$ dry wt). A condition factor was calculated from the length and weight of eels as described by Schäperclaus (1990). Data on the swimming activity of each group are presented as means \pm $\mathrm{SD}$. A Kruskal-Wallis $H$-test or MannWhitney $U$-test was employed to test for 
Table 1. Anguilla anguilla. Swimming duration $(\bar{x} \pm \mathrm{SD})$ in relation to dry weight of Anguillicola crassus

\begin{tabular}{|lcc|}
\hline Dry wt of A. crassus (mg) & No. of eels & Duration (s) \\
\hline Uninfected & 14 & $141 \pm 110$ \\
$0.1-1.0$ & 16 & $169 \pm 137$ \\
$1.1-25.0$ & 19 & $136 \pm 85$ \\
$\geq 25.1$ & 21 & $197 \pm 168$ \\
\hline
\end{tabular}

significant differences $(\mathrm{p} \leq 0.05)$. Spearman's rankcorrelation coefficient was used to test for significant associations between swimming activity and the infection status.

\section{RESULTS}

\section{Swimming activity of eels infected with Anguillicola crassus}

Eels could be grouped into 4 classes based on the dry weight of the nematodes in their swimbladders (Table 1). The duration of swimming activity did not differ significantly between these groups. However, eels with the highest dry weight of nematodes (>25.1 mg) tended to swim longest.

Similar results were obtained when eels were grouped according to the number of adult worms per swimmbladder (Table 2). Eels with 10 or more nematodes seem to swim longer against the current than less infected hosts, but again the differences were not significant. Spearman's rank-correlation analysis did not show any association between the degree of infection with Anguillicola crassus (dry weight and number) and swimming activity (Fig. 2). Furthermore, swimming activity was not correlated with the condition factor of the eels (Spearman $r=0.102 ; \mathrm{p}=0.05$ ).

\section{Swimming activity prior to and after infection with Ichthyophthirius multifiliis}

In contrast to Anguillicola crassus infection, infection of eels with Ichthyophthirius multifiliis significantly reduced the duration of active swimming against the current (Fig. 3). By 4 d post-exposure, 58 of 70 eels ( $83 \%$ ) had become infected with I. multifiliis. On these eels (39 of which were used for the experiments) the protozoan abundance averaged $30.7 \pm 17$ trophozoites $\mathrm{cm}^{-2}$. Prior to infection, the eels swam against the current for $157 \pm 109$ s. This decreased to $83 \pm 53 \mathrm{~s}$ after infection with the ciliate (Fig. 3).
Table 2. Anguilla anguilla. Swimming duration $(\bar{x} \pm \mathrm{SD})$ in relation to number of Anguillicola crassus swimbladder ${ }^{-1}$

\begin{tabular}{|lcc|}
\hline No. of $A$. crassus & No. of eels & Duration (s) \\
\hline 0 & 14 & $141 \pm 110$ \\
$1-5$ & 37 & $177 \pm 131$ \\
$6-10$ & 8 & $149 \pm 119$ \\
$>10$ & 11 & $192 \pm 181$ \\
\hline
\end{tabular}

\section{DISCUSSION}

In the present study, the swimbladder nematode Anguillicola crassus was found in $88.5 \%$ of the eels, a level comparable with that found in other aquatic biotopes in Europe. Sures \& Streit (2001) reported a prevalence of approximately $90 \%$ for the river Rhine near Karlsruhe. Our results from the swimming channel indicate that $A$. crassus does not affect the swimming ability of infected eels in terms of the maximum period of time the eels are able to withstand a current of $0.62 \mathrm{~m} \mathrm{~s}^{-1}$. This corresponds to findings of
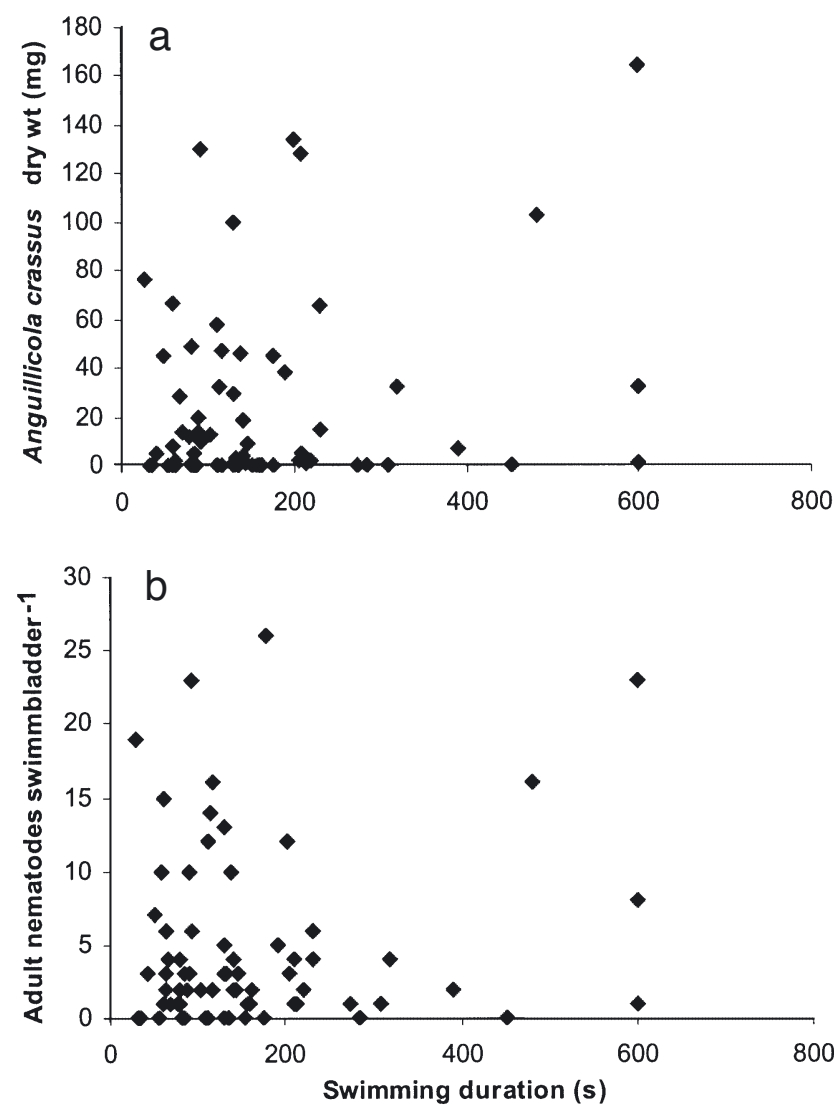

Fig. 2. Anguilla anguilla. Swimming duration in relation to (a) dry weight of Anguillicola crassus and (b) numbers of A. crassus eel ${ }^{-1}$ 


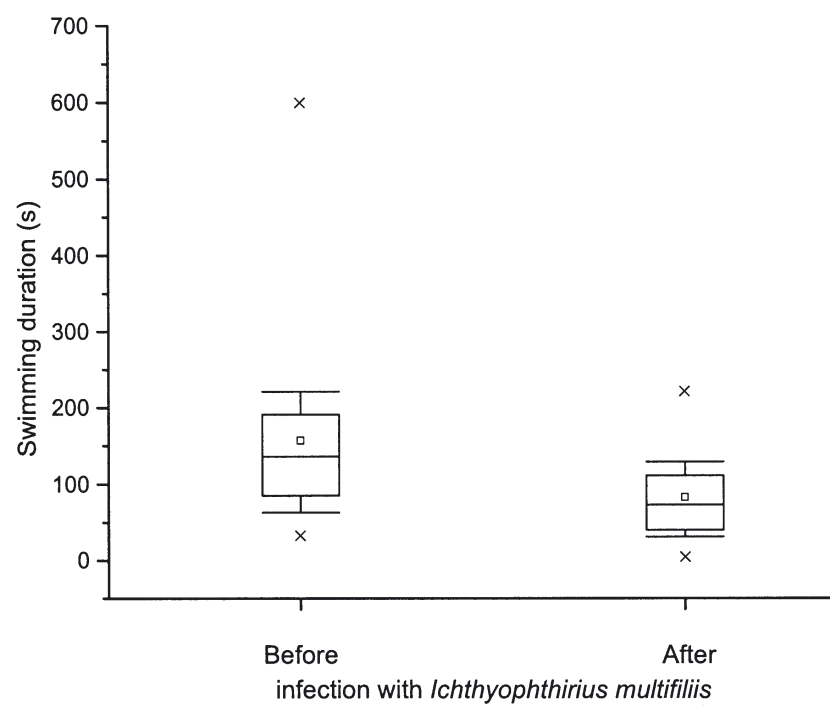

Fig. 3. Ichthyophthirius multifiliis. Swimming activity before and after infection with Ichthyophthirius multifiliis. All measured values are shown: $\times$ : maximum/minimum; $\square$ : arithmetic mean; horizontal line at top, inside and at bottom of box: 25th, 50th, and 75th percentile values respectively. Error bars: 5th and 95th percentiles

Nimeth et al. (2000), who also did not detect any significant difference in swimming activity between uninfected and $A$. crassus-infected glass eels. They measured the 'critical' swimming speed (defined as the speed at which the glass eels were no longer able to swim against the current), and found that at intermediate speeds ( 60 to $80 \%$ of the critical swimming speed) infected fish had a slightly higher locomotion than uninfected control eels.

In contrast to our results and those of Nimeth et al. (2000), Sprengel \& Lüchtenberg (1991) reported an effect of parasites on the swimming performances of eels. They measured the maximum swimming speed of European eels Anguilla anguilla in a circular channel to determine their fitness, and reported reductions in maximum swimming speed in direct parallel to increasing numbers of $A$. crassus. In heavily infected eels ( $\geq 11$ nematodes), swimming ability was reduced by $18.6 \%$ compared to uninfected fish.

We do not know the circumstances under which the apparently conflicting results of Sprengel \& Lüchtenberg (1991) were achieved. The present study comprised parallel experiments using a reference hostparasite model, an approach that proved useful in detecting different effects of various parasites on the locomotion of a host.

Ichthyophthirius multifiliis, a parasite which quickly multiplies on an individual host, considerably affected the swimming behaviour of infected eels. The eels displayed dramatically reduced swimming activity after infection with this parasitic protozoan. Statistically significant differences between swimming activity before and after infection with $I$. multifiliis were revealed by a Mann-Whitney $U$-test. Infected eels swam against the current for $>1$ min less than prior to infection. Thus, their swimming ability was reduced by $47 \%$. In 4 cases, the eels completely lost the ability to withstand the current and they drifted passively into the net at the end of the tube. We interpret this as a clear pathological effect of infection rather than an adaptive behavioural alteration, as this monoxenic parasite would not profit from exposing infected fish to predation reducing their swimming ability. I. multifiliis is well known to have severe pathogenic effects on both the skin and the gill of eels (Ewing \& Kocan 1987, Ewing et al. 1988), causing for instance a lower rate of respiration and thus a loss of fitness, leading to death in fish that are heavily infected.

With regard to Anguillicola crassus, the eel is its final host, and thus an altered locomotary behaviour which increases vulnerability to predation would not be profitable either. According to our results and those of Nimeth et al. (2000), infected eels were even slightly better in swimming against a water current than uninfected controls. This suggests that $A$. crassus infection is associated with an increased short-term energy availability channelled by the endocrine system. Sures et al. (2001) showed that infection with $\mathrm{L}_{3}$-larvae of $A$. crassus resulted in a significant increase in the serum cortisol levels of infected eels. Obviously, the larvae invading the swimbladder wall induce stress in European eels and thus lead to elevated levels of cortisol, which could increase the concentration of plasma carbohydrates providing energy. Cortisol is generally considered a primary messenger of a stress response in teleostean fishes (Barton \& Iwama 1991, Kloas 1999). This might explain the better swimming efficiency in our short-time experiments. However, this should not function in the long-term, and in the experiments by Sures et al. (2001) no elevated cortisol levels were found in eels with mature A. crassus. It should be noted that in the experiments of Sures et al. (2001) the infected eels had not been stressed in any way.

The probability of an eel reaching the spawning grounds in the Sargasso Sea and the speed at which this long-distance migration can be performed will depend on the energy reserves and overall condition of the eel. One of the most important energy reserves is the liver (Wootton 1984, Lambert \& Dutil 1997). The major energy reserve of the eel consists of lipids, which are predominantly stored as triglycerides in muscle tissues (Lewander et al. 1974, Boëtius \& Boëtius 1980) and in the liver (Dave et al. 1975). However, analogous to the results of our swimming experiments, Möller et al. (1991) found no indication of the liver somatic index 
of Anguilla anguilla being influenced by A. crassus, and therefore also no effect on the energy reserves of the host.

In our study the short-term ability to resist a water current was not correlated with the condition of the eels. In nature, the smaller male silver eels start their spawning migration in European inland waters earlier (August, September) than the larger, heavier females (September, October) because they do not attain a swimming speed of more than $\sim 40 \mathrm{~km} \mathrm{~d}^{-1}$. By March, both sexes have arrived at the spawning grounds, and mating commences (Tesch 1999). Inside rivers, silver eels use the currents (especially after heavy rain) for passive displacement towards the sea, where they can float out on the low-tide current. In the open Atlantic, migration takes place at depths mostly below $100 \mathrm{~m}$, where currents do not play a major role. However, eels perform diurnal, vertical, lunar-controlled migrations. On dark nights, migration takes place at depths between $\sim 40$ and $250 \mathrm{~m}$, during the day between 300 and $500 \mathrm{~m}$. For such vertical migrations, an uninfected swimbladder, with unaltered stratification and superficially located, intact gas gland cells would seem to be an essential requirement. Infection by Anguillicola crassus leads to thickening and disorganization of the swimbladder wall, with the superficial gas gland cells losing direct contact to the blood capillaries (Würtz \& Taraschewski 1996). In such swimbladders, oxygen content is decreased, suggesting that the function of this hydrostatic organ is disturbed. Eels with pathologically altered swimbladders may have difficulty in performing vertical migrations, and thus may use up too much of their energy reserves, resulting in a reduced swimming speed and thus a late arrival at the spawning grounds.

In a normal vertebrate mating system individuals of the choosing (usually the female) sex select the fittest mates from a group of several others (Gould \& Gould 1989). In European eels, mating and spawning takes place at a depth of several hundred metres (Tesch 1999), where sexual selection cannot rely on optical cues such as size of pectoral fins, colourful breast, or other mating ornaments reflecting the status of health (Gould \& Gould 1989). Under these circumstances it would be selectively profitable to exclude individuals that arrive late at the spawning ground from reproduction. From an evolutionary viewpoint, Anguilla anguilla would benefit most if 'good genes' which have prevented certain eels from becoming infected could be passed on to offspring, while infected eels serve as reserve mates. Infected late arrivals would comprise both sexes; thus, the earlier arrivals should be present in a balanced male:female ratio, enabling successful reproduction. Eels with a thickened, fibrotic swimbladder wall may be subjected to higher predatory pressure during their slower, vertical migrations, or may suffer high mortality due to other adverse factors. Therefore, the overall reproductive output of the European eel under the impact of Anguillicola crassus is possibly slightly lower than it was before the parasite occurred in Europe, but the selection of 'good genes' is ensured.

It does not seem likely that the decrease in the number of glass eels arriving at the coasts of Western Europe is predominantly caused by Anguillicola crassus preventing silver eels from reaching the Sargasso Sea. Intensive aquacultures rearing European eels in Europe and in China, and various other ecological alterations, such as canalization or the destruction of river systems by power stations, could be more important factors. Also, the decrease in the abundance of glass eels had already begun prior to the spread of $A$. crassus in Europe (Würtz \& Taraschewski 2000). Accordingly, infection of eels with A. crassus is probably only 1 (minor?) factor among an array of threats to the European eel.

Acknowledgements. Thanks are due to Professor H. Buggisch and Professor C. Posten (Institut für Mechanische Verfahrenstechnik und Mechanik) for permitting the use of the swimming channel. The expert repair and assistance of their technical employees in running the swimming channel is gratefully acknowledged. Thanks are also due to Mr. H. Weiher (Institut für Wasserwirtschaft und Kulturtechnik) for lending a flow-meter.

\section{LITERATURE CITED}

Barton BA, Iwama GK (1991) Physiological changes in fish from stress in aquaculture with emphasis on the response and effects of corticosteroids. Annu Rev Fish Dis 1:3-26

Boëtius I, Boëtius J (1980) Lipid and protein content in Anguilla anguilla during growth and starvation. Dana 4: $1-17$

Bonneau S, Blanc G, Petter A (1991) Étude sur la biologie des premiers stades larvaires d'Anguillicola crassus (Nematoda, Dracunculoidea): spécificite de l'hôte intermédiaire et influence de la température sur la durée du développement. Bull Fr Pêche Piscic 320:1-6

Dave G, Johansson-Sjobeck ML, Larsson A, Lewander K, Lidman U (1975) Metabolic and haematological effects of starvation in the European eel, Anguilla anguilla L. I. Carbohydrate, lipid, protein and inorganic ion metabolism. Comp Biochem Physiol A 52:423-430

De Charleroi D, Grisez L, Thomas K, Belpaire C, Ollevier F (1990) The life cycle of Anguillicola crassus. Dis Aquat Org 8:77-84

Egusa S (1979) Notes on the culture of the European eel (Anguilla anguilla) in Japanese eel-farming ponds. Rapp P-V Réun Cons Int Explor Mer 174:51-58

Ewing MS, Kocan KM (1987) Ichthyophthirius multifiliis (Ciliophora) exit from gill epithelium. J Protozool 34: 309-312

Ewing MS, Ewing SA, Kocan KM (1988) Ichthyophthirius (Ciliophora): population studies suggest reproduction in host epithelium. J Protozool 35:549-552 
Gould JL, Gould CG (1989) Sexual selection - mate choice and courtship in nature. Scientific American Library, New York

Hartmann F (1989) Investigations on the effectiveness of Levamisole as a medicationagainst the eel parasite Anguillicola crassus (Nematoda). Dis Aquat Org 7: 185-190

Johnson SK, Loraine TF, Williams J, Huffman DG (1995) Presence of the parasitic swimbladder nematode, Anguillicola crassus, in Texas aquaculture. World Aquacult 26:35-36

Kelly CE, Kennedy CR, Brown JA (2000) Physiological status of wild European eels (Anguilla anguilla) infected with the parasitic nematode, Anguillicola crassus. Parasitology 120:195-202

Kennedy CR (1993a) Introductions, spread and colonization of new localities by fish helminth and crustacean parasites in the British Isles: a perspective and appraisal. J Fish Biol 43:287-301

Kennedy CR (1993b) The dynamics of intestinal helminth communities in tropical eels Anguilla anguilla in a small stream: long-term changes in richness and structure. Parasitology 107:71-78

Kennedy CR, Fitch DJ (1990) Colonization, larval survival and epidemiology of the nematode Anguillicola crassus, parasitic in the eel, Anguilla anguilla, in Britain. J Fish Biol 36: $117-131$

Kloas W (1999) Stress physiology in fish. In: Roubos EW, Wendelaar Bonga SE, Vaudry H, De Loof A (eds) Recent developments in comparative endocrinology and neurobiology, Shaker Publishing BV, Maastricht, p 157-160

Knopf K, Würtz J, Sures B, Taraschewski H (1998) Impact of low water temperature on the development of Anguillicola crassus in the final host Anguilla anguilla. Dis Aquat Org 33:143-149

Knopf K, Naser K, van der Heijden MHT, Taraschewski H (2000a) Humoral immune response of European eel Anguilla anguilla experimentally infected with Anguillicola crassus. Dis Aquat Org 42:61-69

Knopf K, Naser K, van der Heijden MHT, Taraschewski H (2000b) Evaluation of an ELISA and immunoblotting for studying the humoral immune response in Anguillicola crassus infected European eel Anguilla anguilla. Dis Aquat Org 43:39-48

Køie M (1991) Swimbladder nematodes (Anguillicola spp.) and gill monogeneans (Pseudodactylogyrus spp.) parasitic on the European eel (Anguilla anguilla). J Cons Int Explor Mer 47:391-398

Lambert Y, Dutil JD (1997) Can simple condition indices be used to monitor and quantify seasonal changes in the energy reserves of Atlantic cod (Gadus morhua)? Can J Fish Aquat Sci 54:104-112

Lewander K, Dave G, Johansson ML, Larsson A, Lidman U (1974) Metabolic and hematological studies on the yellow and silver phases of the European eel, Anguilla anguilla L. I. Carbohydrate, lipid, protein and inorganic ion metabolism. Comp Biochem Physiol B 47:571-581

Limanskii V, Martem'ianov V, Bekina E, Golovina N (1984) Changes in the electrolyte composition of the blood and muscles in carp infection with Ichthyophthirius multifiliis (Ciliata, Ophryoglenidae). Parazitologiya 18:479-481

Maamouri F, Gargouri L, Ould Daddah M, Bouix G (1999) Occurrence of Anguillicola crassus (Nematoda, Anguillicolidae) in the Ichkeul lake (Northern Tunisia). Bull Eur Assoc Fish Pathol 19:17-19

Möller H, Holst S, Lüchtenberg H, Petersen F (1991) Infection of eel Anguilla anguilla from the river Elbe estuary with two nematodes, Anguillicola crassus and Pseudoterranova decipiens. Dis Aquat Org 11:193-199

Molnár K (1993) Effect of decreased oxygen content on eel (Anguilla anguilla) infected by Anguillicola crassus (Nematoda, Dracunculoidea). Acta Vet Hung 41:349-360

Molnár K (1994) Formation of parasitic nodules in the swimmbladder and intestinal walls of the eel Anguilla anguilla due to infections with larval stages of Anguillicola crassus. Dis Aquat Org 20:163-170

Molnár K, Szakolczai J, Vetési F (1995) Histological changes in the swimbladder wall of eels due to abnormal location of adult and second stage larvae of Anguillicola crassus. Acta Vet Hung 43:125-137

Moravec F (1992) Spreading of the nematode Anguillicola crassus (Dracunculoidea) among eel populations in Europe. Folia Parasitol (České Budějovice) 39:247-248

Moravec F, Konecny R (1994) Some new data on the intermediate and paratenic hosts of the nematode Anguillicola crassus Kuwahara, Niimi \& Itagaki 1974 (Dracunculoidea) a swimbladder parasite of eels. Folia Parasitol 41: $65-70$

Moravec F, Taraschewski H (1988) Revision of the genus Anguillicola Yamaguti 1935 (Nematoda: Anguillicolidae) of the swimbladder of eels, including descriptions of two new species, A. novaezelandiae sp. n. and A. papernai sp. n. Folia Parasitol 35:125-156

Neumann W (1985) Schwimmblasenparasit Anguillicola bei Aalen. Fischer Teichwirt 11:322

Nielsen ME, Buchmann K (1997) Gluathione-s-transferase is an important antigen in the eel nematode Anguillicola crassus. J Helminthol 71:319-324

Nimeth K, Zwerger P, Würtz J, Salvenmoser W, Pelster B (2000) Infection of the glass-eel swimbladder with the nematode Anguillicola crassus. Parasitology 121:75-83

Schäperclaus W (1990) Fischkrankheiten. Akademie-Verlag, Berlin

Schmahl G, Ruider S, Mehlhorn H, Schmidt H, Ritter G (1992) Treatment of fishparasites. 9. Effects of a medicated food containing malachite green on Ichthyophthirius multifiliis Fouquet, 1876 (Hymenostomatida, Ciliophora) in ornamental fish. Parasitol Res 78:183-92

Scholz T (1999) Parasites in cultured and feral fish. Vet Parasitol 84:317-335

Sprengel G, Lüchtenberg H (1991) Infection by endoparasites reduces maximum swimming speed of European smelt Osmerus eperlanus and European eel Anguilla anguilla. Dis Aquat Org 11:31-35

Sures B, Knopf K (2004) Individual and combined effects of Cd and 3, 3', 4, 4',5-pentachlorobiphenyl (PCB 126) on the humoral immune response in European eel (Anguilla anguilla) experimentally infected with larvae of Anguillicola crassus (Nematoda). Parasitology 128:445-454

Sures B, Streit B (2001) Eel parasite diversity and intermediate host abundance in the River Rhine, Germany. Parasitology 123:185-191

Sures B, Knopf K, Taraschewski H (1999a). Development of Anguillicola crassus (Dracunculoidea, Anguillicolidae) in experimentally infected Balearic congers Ariosoma balearicum (Anguilloidea, Congridae). Dis Aquat Org 39: $75-78$

Sures B, Knopf K, Würtz J, Hirt J (1999b) Richness and diversity of parasite communities in European eels Anguilla anguilla of the River Rhine, Germany, with special reference to helminth parasites. Parasitology 119:323-330

Sures B, Knopf K, Kloas W (2001) Induction of stress by the swimbladder nematode Anguillicola crassus in European eels, Anguilla anguilla, after repeated experimental infection. Parasitology 123:179-184 
Székely C (1994) Paratenic hosts for the parasitic nematode Anguillicola crassus in Lake Balaton, Hungary. Dis Aquat Org 18:11-20

Taraschewski H, Moravec F, Lamah T, Anders K (1987) Distribution and morphology of two helminths recently introduced into European eel populations: Anguillicola crassus (Nematoda, Dracunculoidea) and Paratenuisentis ambiguus (Acanthocephala, Tenuisentidae). Dis Aquat Org 3:167-176

Tesch FW (1999) Der Aal. Paul Paray, Hamburg

Thomas K (1993) The life cycle of the eel parasite Anguillicola crassus (Nematoda, Dracunculoidea). Dissertation, Universität Leuven, Belgium

VanBanning P, Haenen OLM (1990) Effects of the swimmbladder nematode Anguillicola crassus in wild and farmed eel, Anguilla anguilla. In: Perkins FO, Cheng TC (eds)

Editorial responsibility: Wolfgang Körting,

Hannover, Germany
Pathology in marine science, Academic Press, New York, p 317-330

Wootton R (1984) A functional biology of sticklebacks. Croom Helm, London

Würtz J, Taraschewski H (2000) Histopathological changes in the swimbladder wall of the European eel Anguilla anguilla due to infection with Anguillicola crassus. Dis Aquat Org 39:121-134

Würtz J, Taraschewski H, Pelster B (1996) Changes in gas composition in the swimbladder of the European eel (Anguilla anguilla) infected with Anguillicola crassus (Nematoda). Parasitology 112:233-238

Würtz J, Knopf K, Taraschewski H (1998) Distribution and prevalence of Anguillicola crassus (Nematoda) in eels Anguilla anguilla of the rivers Rhine and Naab, Germany. Dis Aquat Org 32:137-143

Submitted: October 28, 2003; Accepted: February 19, 2004 Proofs received from author(s): July 30, 2004 